\title{
Tax Aggressiveness Affected by Corporate Social Responsibility, Earnings Management, and Audit Quality
}

\author{
Akuntansi \\ Noveryan Irfansyah $^{1^{*}}$, Icuk Rangga Bawono ${ }^{2}$, Irianing Suparlinah ${ }^{3}$ \\ ${ }^{1,2,3}$ Faculty Economic and Business, Jenderal Soedirman University \\ *Email: Irfansyahnov03@gmail.com
}

\section{ABSTRACT}

This study aims to examine whether tax aggressiveness can be affected by corporate social responsibility, earnings management and audit quality. This study uses manufacturing companies listed on the Indonesia Stock Exchange (BEI) in 2016-2018 as research objects with a total of 165 companies. In determining the sample in this study using a purposive sampling method, and obtained a total sample of 46 companies and a study period of 3 years so that the sample size becomes 138 data units. The results of this study indicate that tax aggressiveness can not be affected by corporate social responsibility, tax aggressiveness can be affected positively and significantly by earnings management and tax aggressiveness can be affected negatively and significantly by audit quality.

Keyword: Corporate Social Responsibility, Earnings Management, Audit Quality, Tax Aggressiveness

\section{INTRODUCTION}

At present, Indonesia's state revenue comes from various sources, one of which is taxation. The tax sector is the Main concern to increase state revenue (Sudibyo \& Bawono, 2016). Because without tax collection conducted by the government, Government programs planned to develop the country will experience obstacles due to lack of state revenue from taxes. Republic of Indonesia Law No. 16 of 2009 concerning general provisions and taxation procedures (KUP), taxes are contributions which have a coercive nature by the state to individuals or entities. Tax are citizen contributions that will be used for the prosperity of the people. Tax has a very important role in the country's economy.

The tax has a function as a source of state revenue and policy regulators to be made by the state. In state revenue, there are several sources from various sectors. But from all sources, the tax sector became the dominant source in state revenue. Over the past 5 years, 
the tax sector has been a source of income for Indonesia compared to other income sectors. Even though tax has become the biggest state revenue compared to other sectors, the last 3 years of tax revenue in Indonesia has experienced constraints in the form of not achieving the target set by the government. Table 1 shows Indonesia's tax revenues from 2016-2018:

Table 1. Tax Revenue Realization (in trillion rupiahs)

\begin{tabular}{lrrr}
\hline \multicolumn{1}{c}{ Year } & $\mathbf{2 0 1 6}$ & $\mathbf{2 0 1 7}$ & \multicolumn{1}{c}{$\mathbf{2 0 1 8}$} \\
\hline Target & $1.539 .166,2$ & $1.472 .709,2$ & 1.618 .090 \\
\hline Realization & $1.284 .970,1$ & $1.343 .529,8$ & 1.518 .078 \\
\hline Percentage & $83,48 \%$ & $91,23 \%$ & $93,86 \%$ \\
\hline
\end{tabular}

Source: Financial Report of Central Government

Based on the data in the table above, state tax revenue does not always reach the target set by the government for the past 3 years. That can be seen starting in 2016-2018, during that year the state tax revenue has increased every year but this increase is not followed by the achievement of the tax revenue target set by the government.

The Directorate General of Taxes (DGT) is the agency responsible for collecting taxes in Indonesia. sources of tax revenue in Indonesia come from individual taxpayers and corporate taxpayers. Corporate taxpayers consist of Limited Liability Companies (PT), private companies and Vennootschaap Commanditaire (CV). State-owned companies such as State-Owned Enterprises (BUMN) and Regionally-Owned Enterprises (BUMD) are also not free from tax collection carried out by the government. Many companies in Indonesia have been classified as state taxpayers. So that companies in Indonesia that get high income will also get higher taxes. Thus, the company will think in order to maximize the benefits of the company by reducing the company's tax burden. Because the higher the tax given by the state to companies, it will make the company's profits lower. This will make the company think to do managerial actions that can make the tax given to the company will be lower than it should, this action is called tax aggressiveness.

Tax aggressiveness is an act of taxable income that is designed by means of tax planning. in this method, it can be done in a legal or illegal manner (Frank et al., 2008). Zuber (2013) in conducting tax planning there are relief and illegal ways. Among these there are gray zones which can cause tax aggressiveness. this gray zone can arise as a result of a tax collection place outside all tax transactions that are permitted by tax law or not.

In carrying out tax aggressiveness, companies have several ways. One way that can be used is CSR. CSR is very closely related to the survival of a company (Lanis and Richardson, 
2012). A company with a low CSR rating will make the company look like a company that is not socially responsible for the environment around the company by the community.

Besides CSR, there are other ways to carry out tax aggressiveness. namely with earnings management. One of the goals of management in managing earnings is the tax objective (Scott, 2015). This is because, in determining the tax a company uses the amount of the company's taxable income reported, thus the company will maintain their profits at a certain level. in reducing the tax burden, companies can do this by increasing or decreasing company profits.

After CSR and earnings management, there are other ways to do tax aggressiveness. That way is audit quality. Companies in selecting auditors will use one important indicator, namely audit quality. An auditor who comes from Big Four Public Accounting Firm will be considered to have higher quality compared to an audit who is not from Big Four Public Accounting Firm. KAP Big Four will have more experience and highly qualified human resources. Thus, it will be able to minimize the tax aggressiveness practices that will be carried out by companies.

The results of research conducted by Suprimarini and Suprasto (2017) states that CSR has a negative effect on tax aggressiveness. But on the contrary, Results from Jessica and Toly (2015) have different results and find that CSR cannot effect tax aggressiveness. Research conducted by Purwanto (2016) for earnings management, found the results that earnings management can positively effect on tax aggressiveness. But the opposite result was found by Ilyani (2018) who stated that earnings management could not affect the tax aggressiveness. And the results of audit quality research from Suyono (2018) found that audit quality in a negative effect on tax aggressiveness. In contrast to Suyono, research from Fatimah et al. (2017) found that audit quality cannot affect tax aggressiveness.

Based on the explanation above, it can be seen that there are still differences of research opinion about the effects caused by CSR, earnings management and audit quality on tax aggressiveness. Therefore, researchers are interested in conducting research with the title "Tax aggressiveness influenced by Corporate Social Responsibility, Earnings Management, and Audit Quality". And manufacturing companies are made by researchers as research objects. 


\section{LITERATURE REVIEW}

Tax Aggressiveness Affected By Corporate Social Responsibility (CSR)

A corporation is a taxpayer who must carry out obligations to the country where the company is located by paying taxes and reporting corporate social responsibility. Limited Liability Company Law No. 40 of 2007 article 1 paragraph 3, states companies must be committed in participating in building a sustainable economy with the aim of improving the quality of life and the environment that can benefit (Otoritas Jasa keuangan, 2016). The legitimacy theory states that a company must be able to create harmony between the social values contained in the company's activities and the norms prevailing in the community around the company (Dowling \& Pfeffer, 1975).

This is also supported by stakeholder theory, where companies must be able to think of the interests of all parties that will be affected by the company's activities (Mustika, 2017). One way to show that a company cares about all stakeholders is to pay taxes.

Muzakki and Darsono (2015) stated that tax aggressiveness can be negatively influenced by CSR. Another matter with Wijayanti et al. (2016) states that tax aggressiveness cannot be influenced by CSR.

H1. Tax aggressiveness can be affected positively and significantly by CSR

\section{Tax Aggressiveness Affected By Earnings Management}

Managers can perform earnings management with the aim to increase or decrease the company's profits in the current period by not reducing or increasing long-term corporate profits (Ilyani, 2018). Tax motivation is one of the reasons companies do earnings management (Novitasari, 2017).

Positive accounting theory explains that companies will engineer profits because they have dealt with political costs, so companies will be able to reduce the political costs imposed on their companies (Wijaya \& Christiawan, 2014). Tax becomes a company problem because it will make the company's net profit decrease, therefore the company will manage the company's revenue in order to reduce the tax burden (Scott, 2000).

Nurhandono and Firmansyah (2017) state that tax aggressiveness can be positively influenced by earnings management. Another case with Ilyani (2018) states that tax aggressiveness cannot be influenced by earnings management.

H2. Tax Aggressiveness can be affected positvely and significantly by Earnings Management 


\section{Tax Aggressiveness Affected By Audit Quality}

Auditor services are needed by the company, it aims to reveal mistakes that occur either unintentionally or intentionally by the company. Thus, auditor quality is very important for the company (Fatimah et al., 2017). Fraudulent financial statements by companies can be influenced by the quality of audits conducted on these companies (Matsumura and Tucker, 1992).

The quality of audits conducted by Big Four KAP will have better audit quality compared to those of KAP who are not Big Four (Tehupuring and Rossa, 2016). In the theory of legitimacy states the ethics owned by the KAP must be in line with the norms and trust of the people in the company environment that they audit. in this case, the legitimacy of the Big Four KAP is greater than the KAP that is not the Big Four due to the level of trust of the people who trust the Big Four KAP (Chrisnovientie \& Raharja, 2012). This happens because, auditors who work at Big Four Public Accounting Firms will try to maintain their big names and reputation, so they will work well (Balsam et al., 2003).

Suyono (2018) states that tax aggressiveness can be negatively influenced by audit quality. Another matter with Fatimah et al. (2017) states that tax aggressiveness cannot be influenced by audit quality.

H3. Tax Aggressiveness can be affected negatively and signifacantly by Audit Quality

\section{METHODOLOGY}

This research is called quantitative research using secondary data. In this study also uses the object of research in the form of corporate social responsibility, earnings management, audit quality and also tax aggressiveness. A total of 165 manufacturing companies listed on the Indonesia Stock Exchange became the population in this study from 2016-2018. After purposive sampling of the population data, a sample of 46 companies was obtained. This study uses multiple linear regression analysis techniques and uses SPSS as a data analysis technique.

\section{Corporate Social Responsibility}

In measuring corporate social responsibility variables, researchers use the Global Reporting Index (GRI). The GRI used is GRI version 4.0 with 91 disclosure items. Calculation of 91 disclosure items is done using scores of 1 and 0,1 for items that are disclosed and 0 for undisclosed items. 


\section{Earnings Management}

In measuring earnings management variables, researchers use Discretional Accrual as a measurement using the Jones model. The Jones Accrual Accrual model is chosen because this model is the best model in detecting earnings management (Alim, 2009).

DA formulation:

$$
D A_{i t}=T A_{i t}-N D A_{i t}
$$

Explanation:

$\mathrm{DA}_{\mathrm{it}}=$ Discretionary accrual of the company in the period to $\mathrm{t}$

NDA $_{\text {it }}=$ Non-Discretionary Accrual of the company at $\mathrm{t}$-period

$\mathrm{TA}_{\mathrm{it}}=$ Total accrual of the company in the $\mathrm{t}$-period

\section{Audit Quality}

In measuring audit quality variables, researchers use dummy variables as measurements. In this case, the researcher uses KAP Big Four and Kap instead of Big Four as a measurement in terms of audit quality. The use of dummy variables is used to give a score of 1 for the Big Four KAP and a score of 0 for the KAP instead of the Big Four. Big Four Public Accountants include Deloitte, Ernst \& Young, PricewaterhouseCoopers, and KPMG.

\section{Tax Aggressiveness}

In measuring tax aggressiveness, researchers use the Effective Tax Rate (ETR) (Putri, 2014). ETR can be sought by dividing income tax expense and income before taxable. In this case, if the ETR value shows a low value then it indicates a high level of tax aggressiveness, conversely if the ETR value shows a high value then it indicates a low level of tax aggressiveness.

The ETR calculation formulation is as follows:

$$
E T R=\frac{\text { Income Tax Expense }}{\text { Income Before Tax }}
$$

\section{RESULTS AND DISCUSSION}

In this study, researchers used secondary data from the Indonesia Stock Exchange (IDX). The population of this research is manufacturing companies that have been listed on the Stock Exchange in 2016-2018. And researchers have done purposive sampling so as to get a sample of 138 samples. This sample came from 46 listed manufacturing companies each year, so as many as 138 samples were collected. In determining the sample for this study, researchers used several criteria that can be seen in table 2 . 
Table 2. Criteria Sample

\begin{tabular}{|c|c|c|}
\hline No & Criteria & Total \\
\hline 1 & $\begin{array}{l}\text { Manufacture company listed on the Indonesia Stock } \\
\text { Exchange (IDX) from 2016-2018 }\end{array}$ & 166 \\
\hline 2 & $\begin{array}{l}\text { Manufacture company that did not have annual } \\
\text { financial reports from 2016-2018 }\end{array}$ & (33) \\
\hline 3 & $\begin{array}{l}\text { Manufacture company that suffered losses from 2016- } \\
2018\end{array}$ & $(31)$ \\
\hline 4 & $\begin{array}{l}\text { Manufacture company experiencing delisting from } \\
\text { 2016-2018 }\end{array}$ & (4) \\
\hline 5 & $\begin{array}{l}\text { Manufacture company which did not use the rupiah } \\
\text { currency in their 2016-2018 annual financial } \\
\text { statements }\end{array}$ & $(28)$ \\
\hline \multirow[t]{2}{*}{6} & Outlier data & $(24)$ \\
\hline & Total research samples & 46 \\
\hline
\end{tabular}

Source: Secondary data 2020

\section{Descriptive Statistic Analysis}

Descriptive statistical analysis in this study aims to determine the output of each variable used in this study. The research variables consist of Corporate Social Responsibility (CSR), Earnings Management (EM), Audit Quality (AQ), and Tax Aggressiveness (TA). Descriptive test results of statistical analysis can be seen in table 3 .

Table 3. Result of statistical descriptive analysis

\begin{tabular}{llrrrr}
\hline & N & \multicolumn{1}{c}{ Min } & \multicolumn{1}{c}{ Max } & \multicolumn{1}{c}{ Mean } & Std. Deviation \\
\hline CSR & 137 & 0.02 & 0.22 & 0.1165 & 0.03872 \\
EM & 137 & 0.55 & 0.84 & 0.6908 & 0.05723 \\
TA & 137 & -0.45 & 4.80 & 2.2844 & 0.79261 \\
Valid N & 137 & & & & \\
(listwise) & & & & & \\
Source: SPSS 2020 & & & & &
\end{tabular}

\section{Corporate Social Responsibility (CSR)}

The variable CSR value has the lowest value of 0.02 with the highest value of 0.22 . The CSR variable also has an average value of 0.1165 and a standard deviation value of 0.03872. In this case, the average value obtained by CSR shows that there are still many companies that do not disclose CSR. Because only $11 \%$ of 91 disclosure items that companies must disclose to report CSR.

\section{Earnings Management (EM)}

The EM variable has the lowest value of 0.55 with the highest value of 0.84 . The EM variable also has an average value of 0.6908 and a standard deviation value of 0.05723 . In 
this case, the average value obtained by EM indicates that the management carried out by the company by increasing company profits. Because the average value shows a positive number. Tax Aggressiveness (TA)

The TA variable has the lowest value of -0.45 with the highest value of 4.80 . The TA variable also has an average value of 2.2844 and a standard deviation value of 0.79261 . In this case, the average value obtained by TA shows that the indications that companies are doing tax aggressiveness are fairly large. Because the average value obtained by the TA is close to 0 , where the smaller the value of ETR, the company's aggressiveness will be even greater.

Table 4. Audit quality frequency distribution

\begin{tabular}{crrrrr}
\hline & & Frequency & Percentage & $\begin{array}{c}\text { Valid } \\
\text { Percentage }\end{array}$ & \multicolumn{2}{c}{$\begin{array}{c}\text { Cumulative } \\
\text { Percentage }\end{array}$} \\
\hline \multirow{3}{*}{ Valid } & 0 & 85 & 61,5 & 62 & 62 \\
\cline { 2 - 6 } & & 52 & 37,6 & 38 & 100 \\
\cline { 2 - 7 } & Total & 137 & 99,1 & 100 & \\
\hline Missing & Sistem & 1 & 0,9 & & \\
\hline Total & & 138 & 100 & &
\end{tabular}

Source: SPSS 2020

\section{Audit Quality}

Can be seen in the results in table 4 showing that as many as 85 companies out of 137 companies that were used as research samples, used the Big Four KAP in auditing their company's financial statements.

\section{CLASSIC ASSUMPTION TEST}

\section{Position of data before normalized by transformation}

In conducting normality testing in this study, researchers used the KolmogrovSmirnov $Z$ test. The Kolmogrov-Smirnov $Z$ test had criteria of $>0.05$, so that the data could be said to be normal. Based on the results obtained by researchers after going through the testing process, the value obtained is 0,000 . It can be concluded that, the data used for this study were not normally distributed. Therefore, the regression model cannot be continued.

Table 5. Normality test result

\begin{tabular}{ll}
\hline & Unstandardized Residual \\
\hline Kolmogorov-Smirnov Z & 5.446 \\
\hline Asymp. Sig. (2 Tailed) & 0.000 \\
\hline
\end{tabular}

Source: SPSS 2020 


\section{Apply the Inverse and Outlier method for Normalize Data}

After the researchers conducted a normality test and the researchers found that the data used were not normally distributed. So, the researchers used data transformation in the form of the Inverse method and also the outlier. A total of 72 samples outlier from this method. So that at the beginning of the study, researchers had 210 samples for the study and currently become 138 research samples

\section{Normality Test}

After the normality test is done again with new data. Researchers managed to get a value of 0.317 . It can be seen that these results can exceed the criteria to be able to pass the test of 0.05 . Therefore, the data can be normally distributed and the researcher can continue the regression model to the next stage.

Table 6. Normality test result

\begin{tabular}{cc}
\hline & $\begin{array}{c}\text { Unstandardized } \\
\text { Residual }\end{array}$ \\
\hline Kolmogorov-Smirnov Z & 0.959 \\
\hline Asymp. Sig. (2 Tailed) & 0.317 \\
\hline
\end{tabular}

Source: SPSS 2020

\section{Multicollinearity Test}

Researchers also conducted a multicollinearity test. In this test, the data can have criteria to pass the multicollinearity test of Tolerance $>0.10$ while VIF (Variance Inflation Factor $)<10$. Researchers get the results as follows, for the values of CSR, EM, and AQ already have Tolerance and VIF values above 0.10 and under 10 . Therefore, the data does not experience multicollinearity and can be continued to the next stage.

\section{Table 7. Multicollinearity Test Result}

\begin{tabular}{ccc}
\hline Variable & \multicolumn{2}{c}{ Collinearity Statistics } \\
\cline { 2 - 3 } & Tolerance & VIF \\
\hline CSR & 0.296 & 3.375 \\
EM & 0.459 & 2.179 \\
AQ & 0.553 & 1.807 \\
\hline
\end{tabular}

Source: SPSS 2020

\section{Heteroscedasticity Test}

Researchers also conducted a heteroscedasticity test. In this test, the glesjer method is used by researchers. For the criteria themselves to be able to pass the test, the data must have a value of more than 0.05 . After researchers conduct research and find the following results, 
for CSR and AQ has a value of less than 0.05 so that the variable occurs heteroscedasticity. But it is different for EM variables having values above 0.05 .

Table 8. Heteroscedasticity Test Result

\begin{tabular}{cc}
\hline Variable & Sig. \\
\hline CSR & 0.039 \\
EM & 0.264 \\
AQ & 0.015 \\
\hline
\end{tabular}

Source: SPSS 2020

\section{Autocorrelation Test}

The researcher also conducted an autocorrelation test. In this test, the Durbin Watson method is used by researchers. For the criteria themselves, the data must not have an autocorrelation with the DW value between $\mathrm{dU}$ and 4-dU. After researchers conducted research and found results that the DW value of 1231 . These results should be compared with the DW table with the following components, significance of $5 \%, \mathrm{n}=138$, and $\mathrm{k}=3$. Based on these components, the value of $\mathrm{dL}=1.6778$ and $\mathrm{dU}=1.7665$ are obtained. Thus, it can be seen that the DW value is still below dU, then the data used is positive autocorrelation.

Table 9. Autocorrelation Test Result

\begin{tabular}{cr}
\hline Information & Result \\
\hline $\mathrm{dL}$ & 1.6778 \\
$\mathrm{dU}$ & 1.7665 \\
$D W$ & 1.231 \\
\hline
\end{tabular}

Source: SPSS 2020

\section{Apply the Transformation of the Cochrane Orcutt Method for Normalized}

After going through all the tests contained in the regression analysis. In this case, the researcher still found that the data used did not pass the test in the heteroscedasticity and autocorrelation section. Therefore, researchers still have to use transformation in order to pass all the tests. Cochrane Orcutt Transformation selected by researchers to be able to pass data. Due to using these transformations, we get a change in the data that originally amounted to 138 and is now 137.

\section{Normality Test}

After retesting the normality test, the results show a value of 0.107 and remain above 0.05 . Thus, the data remains normally distributed. 
Table 10. Normality test result

\begin{tabular}{lcr}
\hline & $\begin{array}{c}\text { Unstandardized } \\
\text { Residual }\end{array}$ \\
\hline Kolmogrov-Smirnov Z & & 1.209 \\
\hline Asymp. Sig. (2-tailed) & & 0.107 \\
\hline Source: SPSS 2020 & &
\end{tabular}

\section{Multicollinearity Test}

After retesting the multicollinearity test, the results show that the CSR, EM and AQ values still have Tolerances and VIFs above 0.10 and below 10. Thus, the data still does not have multicollinearity.

Table 11. Multicollineairty test result

\begin{tabular}{ccc}
\hline \multirow{2}{*}{ Variable } & \multicolumn{2}{c}{ Collinearity Statistics } \\
\cline { 2 - 3 } & \multicolumn{2}{c}{ Tolerance } \\
\hline CSR & 0.776 & 1.289 \\
EM & 0.939 & 1.065 \\
AQ & 0.749 & 1.335 \\
\hline
\end{tabular}

Source: SPSS 2020

\section{Heteroscedasticity Test}

After retesting in the heteroscedasticity section, the results show changes where the CSR and AQ variables already have values above 0.05 . Therefore, all variables in this study did not occur heteroscedasticity.

Table 12. Heteroscedasticity test result

\begin{tabular}{cr}
\hline Variable & \multicolumn{1}{c}{ Sig. } \\
\hline CSR & 0.323 \\
EM & 0.845 \\
AQ & 0.052 \\
\hline
\end{tabular}

Source: SPSS 2020

\section{Autocorrelation Test}

After retesting the autocorrelation section, the results showed a change where the DW value of 1.925 was compared with the DW table with the following components, significance of $5 \%, \mathrm{n}=137, \mathrm{k}=3$, obtained $\mathrm{dU}=1.7665$. Thus the $\mathrm{DW}$ value is between $\mathrm{dU}$ and $4-\mathrm{dU}$, it proves that autocorrelation symptoms have not occurred.

\section{Table 13. Autocorrelation test result}

\begin{tabular}{cr}
\hline Information & \multicolumn{1}{c}{ Result } \\
\hline $\mathrm{dU}$ & 1.7665 \\
4-dU & 2.2335 \\
$\mathrm{DW}$ & 1.925 \\
\hline
\end{tabular}

Source: SPSS 2020 


\section{Multiple Linear Regression Analysis}

Table 14. Multiple Linear Analyzes result

\begin{tabular}{|c|c|c|c|c|}
\hline No & Variable & $\begin{array}{l}\text { Regression } \\
\text { Coefficient }\end{array}$ & $\mathrm{T}_{\text {count }}$ & Sig. \\
\hline 1 & CSR & 0.812 & 0.441 & 0.660 \\
\hline 2 & EM & -5.188 & -4.580 & 0.000 \\
\hline 3 & $\mathrm{AQ}$ & 0.434 & 2.287 & 0.024 \\
\hline \multicolumn{5}{|c|}{$=5.672$} \\
\hline R Square & \multicolumn{4}{|c|}{$=0.164$} \\
\hline Adj. R Square & \multicolumn{4}{|c|}{$=0.146$} \\
\hline $\mathrm{F}_{\text {count }}$ & \multicolumn{4}{|c|}{$=8.725$} \\
\hline $\mathrm{F}_{\mathrm{Sig}}$ & \multicolumn{4}{|c|}{$=0.000$} \\
\hline
\end{tabular}

Based on the results contained in Table 14, the multiple regression equation is:

$$
\mathrm{Y}=\mathbf{5 . 6 7 2}+\mathbf{0 . 8 1 2} \mathrm{X}_{1}-\mathbf{5 . 1 8 8 X _ { 2 }}+\mathbf{0 . 4 3 4 X _ { 3 }}+\mathrm{e}
$$

The regression formula can be explained as follows:

\section{Corporate Social Responisbility (CSR)}

The constant value obtained is 5,672. This shows that every CSR, EM, and AQ has a value of 0 , then ETR has a value of that constant value. CSR has a regression coefficient of 0.182. This result shows that when the CSR value increases by one unit, it will be followed by an increase in ETR value of 0.182, assuming the value of EM and AQ is constant. This indicates that when CSR experiences a higher increase then ETR will also follow, this happens because the CSR value has a positive number. Where the higher ETR value indicates that the level of tax aggressiveness is low.

\section{Earnings Management (EM)}

EM has a regression coefficient of $-5,188$. This result shows that when the EM value increases one level, the ETR value will decrease by the EM coefficient value. Assuming the value of CSR and AQ is constant. This indicates that when EM experiences a higher increase, the ETR will decrease, this is because the EM value has a negative number. Where the lower ETR value indicates that the level of tax aggressiveness is high.

\section{Audit Quality (AQ)}

AQ has a regression coefficient of 0.434 . This result shows that when the AQ value increases one level, the ETR value will increase by the AQ coefficient value. Assuming the value of CSR and EM is constant. This indicates that when AQ has increased higher, Etr will 
also increase, this is because the value of AQ has a positive number. Where the higher ETR value indicates that the level of tax aggressiveness is low.

\section{Coefficient of Determination}

In this study, the $\mathrm{R}^{2}$ value that can be seen in table 14 is 0.164 . This result shows that $16.4 \%$ can be explained by the independent variables in this study and $83.6 \%$ can be explained again by other variables not found in this study.

F-Test

In this study, it had an $\mathrm{F}$ value of 8.725 with a significance level of 0,000 . This value will be compared with table $F$ with the components $\mathrm{df}=\alpha,(\mathrm{k}-1),(\mathrm{n}-\mathrm{k})=0.05,(3-1),(138-3)$, it will get a value of 3.06. Thus, the $\mathrm{F}$ value is greater than the $\mathrm{F}$ value of the table. Thus, the model in this research is feasible to study and CSR, EM, AQ as an independent variable can influence the dependent variable simultaneously.

T-Test

Researchers use the $t$ test to be able to determine the impact of each or the impact of the independent variable simultaneously on the dependent variable. $\mathrm{T}$ test results can be seen as follows:

Table 15. T Test

\begin{tabular}{lrrrr}
\hline Variable & $\begin{array}{l}\text { Regression } \\
\text { Coefficient }\end{array}$ & $\mathrm{T}_{\text {count }}$ & $\mathrm{T}_{\text {table }}$ & Sig. \\
\hline $\mathrm{CSR}$ & 0.812 & 0.441 & 1.65622 & 0.660 \\
\hline $\mathrm{EM}$ & -5.188 & -4.580 & 1.65622 & 0.000 \\
\hline $\mathrm{AQ}$ & 0.434 & 2.287 & 1.65622 & 0.024 \\
\hline Source: SPSS 2020 & & &
\end{tabular}

\section{Explanation based on the results above:}

\section{Corporate Social Responsibility}

CSR has a coefficient value of 0.812 with a significance of 0.660 . This result shows that the first hypothesis is rejected, because the significance exceeds 0.05 . Therefore, CSR variable has no effect on tax aggressiveness.

Earnings Management

EM has a coefficient of -5.188 with a significance of 0,000 . This result shows that the second hypothesis is accepted, because the level of significance is less than 0.05. Thus, when the EM variable experiences an increase it will be followed by a decrease in ETR, where the decreasing value of the ETR will increase the tax aggressiveness level.

Audit Quality 
AQ has a coefficient value of 0.434 with a significance of 0.024 . This result shows that the third hypothesis is accepted, because the level of significance is less than 0.05. So, when the AQ variable increases, it will be followed by an increase in ETR, where the more ETR will increase the level of tax aggressiveness will decrease.

\section{The Research Result Discussion}

\section{Tax Aggressiveness Affected by Corporate Social Responsibility}

The results of this study indicate that there is no influence between CSR and tax aggressiveness. In this study, opposite to the theory of legitimacy used. High and low CSR reports conducted by the company will not make a difference to the tax aggressiveness of the company. Because, in practice companies only make CSR reporting a mere formality, because it has become a provision for companies that have go public (Anita, 2015). This also opposite stakeholder theory, where companies must be able to number one of all parties that will be affected by the existence of the company (Mustika, 2017).

The results of this study are in line with research conducted by Nurjanah (2018) who suggested that there was no influence between CSR and tax aggressiveness. However, research results from Pradnyadari and Rohman (2015) are different, because CSR can have a negative and significant effect on corporate tax aggressiveness.

\section{Tax Aggressiveness Affected by Earnings Management}

The results of this study indicate that there is a positive and significant effect between earnings management and tax aggressiveness. In this study, it is in accordance with positive accounting theory where one of the goals of managers in managing earnings is for tax purposes (Novitasari, 2017). The company that will deal with taxes, therefore the company will do earnings management so that the tax given to the company becomes lower than it should (Wijaya \& Christiawan, 2014). The method used by managers in this case is by increasing company profits (Nurhandono \& Firmansyah, 2017).

The results of this study are in line with research conducted by Nurhandono \& Firmansyah (2017) which suggests that earnings management can have a positive and significant effect on tax aggressiveness. However, contrary to research Ilyani (2018) who found that there is no effect that occurs between earnings management and tax aggressiveness. 


\section{Tax Aggressiveness Affected by Audit Quality}

The results of this study indicate that there is a negative and significant effect between audit quality and tax aggressiveness. In this study, it is in accordance with the theory of legitimacy in which the KAP must have ethics and norm systems that are in line with the community, so that the KAP gets public trust. Auditors who come from Big Four Public Accountant Firm will be serious in carrying out their work so that the company's good name will be well protected and will not be damaged due to errors that occur in conducting audits (Chrisnovientie \& Raharja, 2012).

The results of this study are in line with those carried out by Suyono (2018) who suggested that there was a negative and significant effect between audit quality and tax aggressiveness. However, contrary to research from Kusuma \& Firmansyah (2018) which found that audit quality has no effect on tax aggressiveness.

\section{CONCLUTIONS AND IMPLICATION}

\section{Conclusion}

Based on the results of research that has been done, researchers can conclude the following results: (1) Tax Aggressiveness can not be affected by corporate social responsibility, (2) Tax aggressiveness can be affected positively and significantly by earnings management, (3) Tax aggressiveness can be affected negatively and significantly by audit quality.

\section{Implications}

\section{Implication of Theoretical}

In this study, the results of the study are in line with the theory used, namely the theory of legitimacy and positive accounting theory. This study also provides an overview of what can affect tax aggressiveness undertaken by companies. And it is hoped that this research can be a reference to future researchers.

Implication of Practical

The results of this study can be useful for companies, investors, government. For companies, companies are expected to help to reduce tax aggressiveness practices. Because, the importance of taxes to be received by the state so companies must realize that and be more aware of paying taxes in accordance with applicable regulations. It is also hoped that the company will not engage in tax aggressiveness practices, as this will threaten the company's reputation. 
For investors, investors are expected to be more careful in reading the financial statements of a company. So that in making decisions, investors will not be wrong in taking the wrong step.

For government, the government is expected to further strengthen the current tax regulations, so companies will be more difficult when they want to do tax aggressiveness. For tax officials also must be more careful in reading the company's financial statements, because with the long increase does not mean the company does not do tax aggressiveness.

\section{Limitation And Suggestions}

The independent variable contained in this study was only able to explain by $16.4 \%$. While as much as $83.6 \%$ can be explained by other variables not included in this study, so that future research can add other variables to this kind of research going forward.

In this study using ETR measurements in measuring tax aggressiveness. For future research, it is expected to use other measurement methods. Because the tax aggressiveness measurement method does not only use ETR, but there is a Cash Effective Tax Rate (CETR) and Book Tax Different (BTD).

\section{REFERENCE LIST}

Alim, S. (2009). Manajemen Laba dengan Motivasi Pajak pada Badan Usaha Manufaktur di Indonesia. Jurnal Keuangan dan Perbankan, 13(3).

Anita, M. F. (2015). Pengaruh Corporate Social Responsibility, Leverage, dan Ukuran Perusahaan terhadap Agresivitas Pajak. Jurnal FEKON, 2(2).

Balsam, S., J., Krishnan, \& Joon, S., Y. (2003). Auditor Industry Specialization and Earning Quality. SSRN.

Chrisnovientie, D. \& Raharja, S. (2012). Pengaruh Ukuran KAP dan Spesialis Industri KAP terhadap Kualitas Audit: Tingkat Risiko Ligitasi Perusahaan sebagai Variabel Moderasi. Diponegoro Journal of Accounting, 1(1

Deegan, C. (2004). Financial Accounting Theory. Sydney: McGraw-Hill

Dowling, J. \& Pfeffer, J. (1975). Organizational Legitimacy: Social Values and Organozational Bhavior. Pacific Sociological Review, Vol. 18, .122-136

Fatimah, H., Kasyful Anwar, M. \& Nordiansyah, S. P. T. (2017). Pengaruh Intensitas Modal, Kompensasi Eksekutif Dan Kualitas Audit Terhadap Tindakan Penghindaran Pajak Pada Perusahaan Manufaktur Yang Terdaftar Di Bursa Efek Indonesia. Prosiding Seminar Nasional ASBIS.

Feranika, A. (2014). Pengaruh Kepemilikan Institusional, Dewan Komisaris Independen, Kualitas Audit, Komite Audit, Karakter Eksekutif, dan Leverage Terhadap Tax 
Avoidance (Studi Empiris Pada Perusahaan Manufaktur di Bursa Efek Indonesia dengan Tahun Pengamatan 2010-2014). Jurnal Akuntansi Dan Keuangan Universitas Jambi.

Frank, M. M., Lynch, L. J. \& Rego, S. O. (2008). Tax reporting aggressiveness and its relation to aggressive financial reporting. Accounting Review, 84(2).

Freeman, R. E. (1984). Strategic Management: A Stakeholder Approach. Boston: Pitman Publishing

Global Reporting Initiative. Pedoman Pelaporan Berkelanjutan.

Ghozali, I. \& Chariri (2007). Teori Akuntansi. Semarang: Penerbit Undip

Ilyani, R. (2018). Pengaruh Manajemen Laba, Kualitas Audit, Kepemilikan Institusional dan Ukuran Perusahaan Terhadap Agresivitas Pajak (studi empiris pada perusahaan Manufajtur sub Sektor Makanan dan Minuman yang terdaftar di BEI tahun 2014-2016). Fakultas Ekonomi Dan Bisnis Universitas Riau, 1.

Jessica \& Toly, A. A. (2015). Pengaruh Pengungkapan Corporate Social Responsibilty Terhadap Agresivitas Pajak. Tax \& Accounting Review, 4(1).

Kementerian Keuangan (2013). Undang-Undang Ketentuan Umum dan Tata Cara Perpajakan dan Pelaksanaannya.

. (2016). Laporan Keuangan Pemerintah Pusat. Di akses sejak 8 April 2019

. (2017). Laporan Keuangan Pemerintah Pusat. Di akses sejak 8 April 2019.

. (2018). Laporan Keuangan Pemerintah Pusat. Di akses sejak 8 April 2019.

Kusuma, C. \& Firmansyah, A. (2018). Manajemen Laba, Corporate Governance, Kualitas Auditor Eksternal Dan Agrasivitas Pajak. Jurnal Tekun, 8(1)

Lanis, R. \& Richardson, G. (2012). Corporate Social Responsibility \& Tax Aggressiveness: An Empirical Analysis. Journal of Accounting \& Public Policy, 31(1)

Matsumura, E. M. \& Tucker, R. R. (1992). Fraud Detection - a Theoritical Foundation. The Accounting Review, 67(4).

Mustika (2017). Pengaruh Corporate Social Responsibility, Ukuran Perusahaan, Profitabilitas, Leverage, Capital Intensity dan Kepemilikan Keluarga terhadap Agresivitas Pajak (Studi Empiris pada Perusahaan Pertambangan dan Pertanian yang Terdaftar di Bursa Efek Indonesia P. Jurnal Online Mahasiswa Fakultas Ekonomi Universitas Riau, 4(1).

Muzakki, M. R. \& Darsono (2015). Pengaruh Corporate Social Responsibility Dan Capital Intensity Terhadap Penghindaran Pajak. Diponegoro Journal of Accounting, 4(3).

Nasser et al. (2006). Auditor-client relationship: The case of audit tenure and auditor switching in Malaysia. Managerial Auditing Journal, 21(7).

Novitasari, S. (2017). Pengaruh Manajemen Laba, Corporate Governance, dan Intensitas Modal Terhadap Agresivitas Pajak Perusahaan (Studi Empiris pada Perusahaan Property dan Real Estate yang Terdaftar di BEI Periode Tahun 2010-2014). 
Jurnal Online Mahasiswa Fakultas Ekonomi Universitas Riau, 4(1).

Nurhandono, F. \& Firmansyah, A. (2017). Lindung Nilai, Financial Leverage, Manajemen Laba, dan Agresivitas Pajak. Jurnal Media Riset Akuntansi, Auditing dan Informasi, 17(1).

Nurjanah, Ismaeni. (2018). Pengaruh Likuiditas, Leverage, Corporate Social Responisbility, Ukuran Perusahaan, dan Komisaris Independen terhadap Agresivitas Pajak Badan (Studi Empiris Pada Perusahaan Pertanian dan Pertambangan yang terdaftar di Bursa Efek Indonesia Tahun 2012-2016). Repository Unimus.

Otoritas Jasa Keuangan (2016). Limited Liability Company Law No. 40 of 2007. Retrivied from 30 April 2019.

Pradnyadari, I Dewa A. I. \& Rohman, A. (2015). Pengaruh Pengungkapan Corporate Social Responsibility Terhadap Agresivitas Pajak. Diponegoro Journal of Accounting, $4(2)$.

Purwanto, A. (2016). Pengaruh Likuiditas, Leverage, Manajemen Laba, Dan Kopensasi Rugi Fiskal Terhadap Agresivitas Pajak Perusahaan Pada Perusahaan Pertanian Dan Pertambangan Yang Terdaftar Di Bursa Efek Indonesia Periode 2011-2013. Jurnal Online Mahasiswa Fakultas Ekonomi Universitas Riau, 3(1).

Putri, L. T. Y. (2014). Pengaruh Likuiditas, Manajemen Laba dan Corporate Governance Terhadap Agresivitas Pajak Perusahaan (Studi Empiris Pada Perusahaan Yang Terdaftar Di BEI Periode 2008-2012). Jurnal Akuntansi, 2(3).

Scott, W. R. (2000). Financial Accounting Theory (Second). Toronto: Pearson Prentice Hall.

Scott, W. R. (2015). Financial Accounting Theory (Seventh). Toronto: Pearson Prentice Hall.

Suchman, M., C. (1995). Managing Legitimacy: Strategic and Institutional Approaches. The Academy of Management Review, 20(3).

Sudibyo, Y. A. \& Bawono, I. R. (2016). Determinants of Effective Tax Rate in Indonesia. The Indonesia Journal of Accounting Research, 19(1).

Suprimarini, N. P. D. \& Suprasto H. B. (2017). Pengaruh Corporate Social Responsibility, Kualitas Audit, Dan Kepemilikan Institusional Pada Agresivitas Pajak. E-Jurnal Akuntansi Universitas Udayana, 19(2).

Suyono, E. (2018). External Auditors' Quality, Leverage, and Tax Aggressiveness: Empirical Evidence From The Indonesian Stock Exchange. Media Ekonomi Dan Manajemen, 33(2).

Tehupuring, R. \& Rossa, E. (2016). Pengaruh Koneksi Politik dan Kualitas Audit Terhadap Praktik Penhindaran Pajak di Lembaga Perbankan Yang Terdaftar di Pasar Modal Indonesia Periode 2012-2014. Prosiding Seminar Nasional INDOCOMPAC.

Watson, L. (2011). Corporate Social Responsibility, Tax Avoidance, and Tax Aggressiveness: An Examination of Unrecognise Tax Benefits. Social Sience Research Network.

Watts, Ross L. \& Zimmerman, Jerold L. (1986). Positive Accounting Theory: A Ten Years Perspective. USA: Prentice Hall. 
Wibisono. (2007). Membedah Konsep dan Aplikasi CSR. Gramedia: Jakarta

Wijaya, V. A. \& Christiawan, Y. J. (2014). Pengaruh Kompensasi Bonus, Leverage, dan Pajak terhadap Earnings Management pada Perusahaan yang Terdaftar di Bursa Efek Indonesia Tahun 2009-2013. Tax \& Accounting Review. 4(1).

Wijayanti, A., Wijayanti, A. \& Samrotun, Y., C. (2016). Pengaruh Karakteristik Perusahaan, GCG, dan CSR terhadap Penghindaran Pajak. Seminar Nasional IENACO.

Zuber, J. M. \& Sanders, D. L. (2013). The Influence of Attraction and Company Values on Aggressive Corporate Tax Decision-Making. Journal of Accounting, Ethics \& Public Policy, 14(2). 